\title{
31st Annual Meeting of the British Society of Gastroenterology
}

In addition to the scientific papers, of which the abstracts are printed in this number, the annual Sir Arthur Hurst Memorial Lecture was given by Dr Kurt J. Isselbacher on 'Intestinal absorptionstructural and functional aspects'.

An interesting innovation this year was the introduction of educational symposia, in addition to the scientific papers. Professor A. W. Kay acted as Chairman for the symposium on 'Coordination of gastroduodenal function', with E. L. Blair, I. E. Gillespie, and K. Wormsley taking part. Dr Roger Williams arranged a symposium on the 'Treatment of fulminant hepatic failure', with contributions from Dr P. T. Flute, Dr J. Winch, and from himself. In addition, a quite outstanding progress report on 'Immunology and the gut' was given by Professor J. R. Hobbs, and it will long remain in the memory of all those who were present.

There were innovations also in relation to the demonstrations. There were two tape and slide lectures from the American Gastroenterological Association illustrated lecture series, both by Dr A. F. Hofmann, one on 'Fat digestion' and the other on 'The enterohepatic circulation of bile acids'. A slide quiz had been arranged by Professor B. N. Brooke and Dr G. Thompson, and a further slide-tape demonstration, 'Liver biopsy in the diagnosis of acute jaundice', by Dr P. J. Scheuer. As a last minute addition to the programme there was a colour film entitled 'Duodenoscopy', and this was presented by $\mathrm{Dr}$ W. M. M. Classen from Erlanger, West Germany. This was a brilliant film of great interest and delightfully commented on by $\mathrm{Dr}$ Classen in perfect English.

In the Library, the Harveian Librarian, Dr C. E. Newman, and his staff had arranged a historical demonstration, entitled 'Landmarks in gastroenterology'. In this demonstration many well known names in gastroenterology were to be found, with the descriptions of diseases and natural phenomena being set out in the original text. Here one could browse over the books of those who had made such major contributions in the past: Van Helmont, with his description of digestion as a process of fermentation; Wharton's description of the submaxillary salivary gland; William Prout who first proved that gastric juice contained free hydrochloric acid; Cruvheilier's fine illustrations of gross pathology; the original account of acute ulceration of the duodenum in cases of burns by T. B. Curling-being but a few of the many exhibits to be seen, and a demonstration of the most remarkable collection of historical books which is in the possession of the Royal College of Physicians of London.

On display and on sale was the Selected writings of Sir Arthur Hurst, the founder of the British Society of Gastroenterology. This publication brings together much of the work of this great twentieth century gastroenterologist who laid the foundations of so much subsequent work. The Society will long be indebted to $\mathrm{Dr}$ T. C. Hunt for bringing together these historic papers which can all be re-read for the first time with interest and advantage by all working in this field. Medical history, presented in this way, illustrates so well the lessons of success and failure which can help later generations. This is a book which should be in the possession of every member of the Society and in every important library around the world. The publication was devised initially to provide a presentation to those who gave the annual Sir Arthur Hurst memorial lecture, and specially bound copies have been provided for this purpose. 
THE USE OF GASTRIC FUNCTION TESTS BY MEMBERS OF THE BRITISH SOCIETY OF GASTROENTEROLOGY

J. H. BARON and J. ALEXANDER WILliams (Departments of Surgery, Royal Postgraduate Medical School, London, and the General Hospital, Birmingham) A postal questionnaire was returned by $78 \%$ of 259 clinician members of the British Society of Gastroenterology and the replies of 108 physicians and 75 surgeons are reported. Their choice of gastric function tests and rationale for their use have been analysed and compared with criteria suggested recently (Baron, 1970).

Pentagastrin (73\%) has largely replaced older drugs (histamine $16 \%$, histalog $8 \%$ ) as the stimulant of choice for evoking maximal acid secretion. Potentially dangerous insulin tests are being used in situations where they are unlikely to be helpful. In the assessment of patients with proven or suspected ulcers of the stomach and duodenum significantly fewer physicians than surgeons measure gastric acid, and they use these tests less often. The reluctance of physicians to test patients with uninvestigated dyspepsia or gastric ulcer seems justified but in patients having dyspepsia with negative $x$-rays, or after gastrectomy or vagotomy, the greater investigative keenness of surgeons seems commendable. It is to be regretted that only half the surgeons have tried to assess the completeness of their vagotomies and in only one-third of this half is it their usual practice. In patients with $x$-ray evidence of duodenal ulcer, it is surprising that (a) $80 \%$ of the gastroenterologists measure acid at least sometimes; (b) these tests influenced more than half the physicians and two-thirds of the surgeons in deciding whether operation should be advised; (c) half the surgeons were influenced by these tests in deciding the type of operation.

\section{REFERENCE}

Baron, J. H. (1970). Scand. J. Gastroent., Suppl. 6, 9.

THE RELATIONSHIP OF GASTRIC SECRETION TO ANAEMIA OVER 15 YEARS FOLLOWING VAGOTOMY AND GASTROENTEROSTOMY

E. JEAN WHELDON, C. W. VENABLES, and IVAN D. A. JOHNSTON (Department of Surgery, Royal Victoria Infirmary, Newcastle upon Tyne) In previous studies we have shown that anaemia is common following vagotomy and gastroenterostomy $(43.5 \%$ men and $84 \%$ women). The cause of this anaemia was mainly iron deficiency but how it occurred was not clear.

A study was planned in two groups of patients to see if the anaemia was related to changes in gastric secretion induced by the operation. One group consisted of 12 patients whose haemoglobin concentration was less than $10.2 \mathrm{~g} \%$, the second group were patients who, at review, were not anaemic and who had never been treated for anaemia. The gastric secretory response of acid and pepsin to pentagastrin $(6 \mu \mathrm{g} / \mathrm{kg} \mathrm{im})$ and insulin $(0 \cdot 2$ units $/ \mathrm{kg})$ was measured, secretion being collected by a 'washout' technique which gave an estimate of losses. The mean acid output for the anaemic group was $1.12 \mathrm{~m}$-equiv/hr and pepsin output $0.4 \mathrm{mg} / \mathrm{hr}$. These studies were repeated following correction of the anaemia and iron deficiency to confirm that hypochlorhydria did not result from the iron deficiency. After correction, mean acid output was $1.56 \mathrm{~m}$-equiv/hr and pepsin output was $25.7 \mathrm{mg} / \mathrm{hr}$. In the second group the mean acid output in response to pentagastrin was $9.62 \mathrm{~m}$-equiv/ $\mathrm{hr}$ and the pepsin output $108.8 \mathrm{mg} / \mathrm{hr}$. The difference in acid and pepsin output between the anaemic and non-anaemic patients was highly significant $(\mathrm{P}<0.005)$. Only one patient without anaemia had an acid output within the range of the anaemic group.

These findings suggest that anaemia following vagotomy and gastroenterostomy is related to changes in gastric secretion and makes us question whether ? the aim of surgery should be to produce the greatest reduction in acid secretion that is possible.

EFFECT OF LUMINAL $p H$ ON INTESTINAL ABSORPTION OF WATER AND ELECTROLYTES

B. ROUSSEAU and G. E. SLADEN These studies were undertaken because it is often assumed that a reduction of luminal $p \mathrm{H}$ may be in part responsible for the fluid diarrhoea, which occurs in some patients with the Zollinger-Ellison syndrome and with various forms of sugar intolerance. There is evidence that small reductions of $p \mathrm{H}$ may profoundly affect jejunal $\stackrel{\mathbb{D}}{-}$ transport of water and sodium(McHardy and Parsons, $\vec{\varphi}$ 1957), but little is known about such effects of $p H$ in the ileum or colon. In these studies, using rats in vivo, isotonic fluid buffered at different $p \mathrm{Hs}$ $(5 \cdot 6-7 \cdot 6)$ was placed in tied loops of distal ileum $(20-30 \mathrm{~cm})$ or proximal colon $(5-8 \mathrm{~cm})$ and left for short absorption periods (30-45 minutes).

In the ileum, appreciable absorption of water, sodium, and chloride took place from solutions of $p H$ 7.6; negligible absorption of water or sodium occurred at $p \mathrm{H} 6.6$ or $5 \cdot 6$. Significant chloride absorption occurred, however, at all $\mathrm{pHs}$ and this is probably mediated by a separate anion exchange mechanism. In the colon, net absorption took place at all the $p \mathrm{Hs}$ studied. The optimal $p \mathrm{H}$ was 6.6 and the lowest absorption rates were from solutions of pH 5.6.

These studies show that luminal $p \mathrm{H}$ may greatly affect ileal handling of fluid and electrolytes, whereas colonic function is less affected by $p \mathrm{H}$ changes of the same magnitude. Changes in luminal $p \mathrm{H}$, especially in the small intestine, may therefore play an important role in the production of fluid diarrhoea.

\section{REFERENCE}

McHardy, G. J. R., and Parsons, D. S. (1957). Quart. J. exp. Physiol., 42, 33.

STUDIES ON BIDIRECTIONAL SODIUM FLUXES ACROSS THE $\mathscr{\mathcal { D }}$ INTESTINAL MUCOSA IN CHOLERA PATIENTS

A. H. G. LOVE, J. E. ROHDE, and N. VEALL (Department of Medicine, The Queen's University, Belfast, N. Ireland, Pakistan-SEATO Cholera Research Laboratory, Dacca, ¿ Pakistan, and Radioisotopes Division, MRC Clinical Research Centre, Harrow) The diarrhoea of cholera reflects a net difference between the amount of sodium 응 passing into the gut lumen and the amount absorbed from the gut. Whether it is due to impaired absorption or increased secretion has remained a matter for $\stackrel{?}{\rightleftharpoons}$ 
speculation which can only be resolved by bidirectional flux measurements.

Studies have been carried out in normal subjects and cholera patients using whole gut steady-state perfusion techniques. Sodium isotopes were administered orally and intravenously simultaneously. Stochastic analysis of the subsequent activity curves in the blood and stool allowed calculations to be made of the bidirectional fluxes across the intestinal mucosa.

The results obtained show that exogenous and endogenous sodium are handled in a similar fashion by the intestine and that sodium ion exchange occurs predominantly in the upper region of the small intestine. Both inward and outward fluxes are considerably reduced in cholera but absorption is reduced to a greater extent than secretion, resulting in diarrhoea. Segmental studies further confirm this imbalance of sodium ion fluxes and also define more clearly the region of the intestine maximally involved.

SODIUM, POTASSIUM, AND WATER ABSORPTION BY NORMAL HUMAN RECTUM

C. J. EDMONDS (MRC Department of Clinical Research, University College Hospital Medical School, London $W C 1)$ It has recently been claimed that normal human rectum 'fails to absorb electrolytes and water' (Devroede and Phillips, 1970). However, by a new method which will be described, it has been possible to show that not only do significant ionic movements occur but that rectal mucosa possesses a powerful sodium-absorbing mechanism. The unidirectional sodium efflux rate (plasma-to-lumen flux) was small by comparison with that of proximal colon, probably indicating restricted permeability to passive sodium movement. The sodium influx rate (lumen-to-plasmaflux) was considerably greater and the striking characteristic was that sodium absorption occurred against considerable electrochemical gradients. Thus, even when luminal sodium concentration was only $10 \mathrm{~m}$-equiv/1 and the epithelial charge was 20 to $40 \mathrm{mV}$ (blood side positive), the sodium absorption still occurred. Potassium also crossed the epithelium in both directions, zero net movement usually being found only when the luminal concentration exceeded 40 to $50 \mathrm{~m}$-equiv/l. It is unlikely that passive processes dependent upon the electrochemical gradients account for the observations and active secretion of potassium into the lumen seems likely. Water absorption was observed in most experiments but changing the direction of net water flux by altering the osmotic gradient did not significantly affect sodium or potassium movements or the electrical potential difference.

Thus, although total ionic movements are less than in proximal colon, the rectal epithelium cannot be regarded as inactive in respect to electrolyte and water transport. The particular properties of rectal mucosa, especially the ability to absorb sodium actively against large electrochemical gradients, and probably also to secrete potassium, are well adapted to the normal function of the distal gut.

\section{REFERENCE}

Devroede, G. J., and Phillips, S. F. (1970). Gut, 11, 438.
SPONTANEOUS DUODENO-COLIC FISTULA

C. B. JONES (Department of Gastroenterology, Manchester Royal Infirmary) Duodeno-colic fistulae are uncommon. In all previously reported cases they have arisen secondary to some other pathology, either in the duodenum, colon, or elsewhere. Three identical cases of spontaneous communication between the third part of the duodenum and transverse colon are described.

The three cases described and illustrated occurred in two females and one male. The patients were all middle aged and had a history of diarrhoea, general ill health, and emaciation. Following removal of the fistulae, all symptoms were relieved.

In order to find the fistula a careful search was necessary; indeed one patient had previously undergone a laparotomy when the fistula had not been detected.

Microscopy showed that all coats of the bowel were represented within the fistulous track. The mucous membrane and muscular coats of the large and small bowel continued into one another. There was no evidence of any accompanying pathological process.

In the absence of any other pathological lesions, it is postulated that there is an embryological basis for the development of this unusual type of internal intestinal fistula.

${ }^{75}$ Se ACTIVITY IN THE DUODENAL TEST MEAL ASPIRATE: A NEW PANCREATIC FUNCTION TEST

G. R. YOUNGS, I. A. D. BOUCHIER, J. E. AGNEW, and G. E. LEVIN (Departments of Medicine, Physics and Chemical Pathology, The Royal Free Hospital,London) The pancreas selectively takes up ${ }^{75} \mathrm{Se}$-selenomethionine and incorporates the isotope into secretory proteins. In this study we have evaluated the appearance of ${ }^{75} \mathrm{Se}$ in human duodenal aspirate and have used the information as a test of pancreatic exocrine function. Intravenous ${ }^{75} \mathrm{Se}$-selenomethionine in a dose of $3 \mu \mathrm{Ci} / \mathrm{kg}$ body weight was given 10 minutes after drinking a Lundh test meal and a pancreatic scan and duodenal aspiration were then performed simultaneously. In patients not undergoing a pancreatic scan one tenth of the dose of isotope was given. In normal subjects the level of ${ }^{75} \mathrm{Se}$ in the duodenal aspirate remained low for one hour and then rose rapidly, whereas in patients with diffuse pancreatic damage no such increase occurred. There was a significant correlation between the ${ }^{75} \mathrm{Se}$ activity at two hours and the trypsin concentration of the aspirate. The level of ${ }^{75} \mathrm{Se}$ activity remained low in bile and gastric juice. The results suggest that the ${ }^{75} \mathrm{Se}$-selenomethionine is incorporated into the enzymes released in the pancreatic juice and that measurement of ${ }^{75} \mathrm{Se}$ activity in the duodenal aspirate is a useful index of pancreatic function. Under certain circumstances this may prove a simpler test of pancreatic function than estimation of trypsin ac:ivity.

\section{GALLBLADDER INERTIA IN ADULT COELIAC DISEASE}

T. S. LOW-BEER, K. W. HEATON, and A. E. READ (Department of Medicine, University of Bristol) Since the physiological stimulus to gallbladder contraction is cholecystokinin released from the proximal small 
intestine in response to food, we have investigated this process in patients with adult coeliac disease. All patients had subtotal villous atrophy on peroral biopsy and were not on a gluten-free diet. The techniques used were measurement of radioactive bile salt turnover (Austad, Lack, and Tyor, 1967) and metabolism (Garbutt, Heaton, Lack, and Tyor, 1968) and oral cholecystography.

The results showed that, compared with control subjects, labelled taurocholate remained in the bile for longer and was metabolized more slowly in six out of eight patients with coeliac disease. This suggests that bile salts were being sequestered in an essentially sterile part of the enterohepatic circulation, presumably the gallbladder. Nevertheless, injected cholecystokinin caused a copious flow of concentrated bile into the duodenum of intubated patients.

Oral cholecystography in 13 patients with adult coeliac disease showed normal concentration of the contrast mediuın in all patients but in eight of them there was little or no contraction in response to a fatty meal. A control series matched for age and sex showed good contraction in 17 out of 20 subjects.

We therefore suggest that in many patients with mucosal disease of the upper small intestine synthesis or release of endogenous cholecystokinin is impaired, resulting in gallbladder inertia. This could contribute to the production of steatorrhoea.

\section{REFERENCES}

Austad, W. I., Lack, L., and Tyor, M. P. (1967). Gastroenterology, $52,638$.

Garbutt, J., Heaton, K. W., Lack, L., and Tyor, M. P. (1968). (Abstr.) Gastroenterology, 54, 1234.

IMMUNOLOGICAL STUDIES OF A COMMUNITY OUTBREAK OF HEPATITIS

A. B. AJDUKIEWICZ, R. A. FOX, F. DUDLEY, S. SHERLOCK, D. DONIACH, S. DEL PRETE, and D. CONSTANTINO (Department of Medicine, Royal Free Hospital, Department of Immunology, Middlesex Hospital, Istituto di Clinica Medica 11, Milan) Serial sera were obtained from 72 patients with infective hepatitis in Tilbury. The incubation period was two to three weeks in the majority. Threequarters of those affected were less than 15 years of age. The sera were negative when tested for the usual hepatitis-associated antigen. Using an antiserum from Milan positive results were obtained in 39 patients. Most patients gave positive tests in the first two weeks of illness. Sera obtained later in the course of the illness and convalescent sera were both negative. The incidence of smooth muscle antibody was $68 \%$. Higher titres tended to occur earlier in the course of the illness and in most of these cases tests with the Milan antiserum were positive. The titre of smooth muscle antibody gradually fell. Mitochondrial antibodies were uniformly negative. The results using the Milan antiserum suggest that short incubation epidemic infective hepatitis is virologically a different illness from that associated with the hepatitis-associated antigen, but that the tissue antibody responses are similar to those in hepatitis associated with hepatitis-associated antigen.

A TRIAL OF AZATHIOPRINE IN PRIMARY BILIARY CIRRHOSIS

A. ROSS and S. SHERLOCK (Department of Medicine,
Royal Free Hospital, London) A controlled trial of immunosuppressive therapy in patients with primary $\Omega$ biliary cirrhosis (PBC), has been in progress for two years. Thirty-one patients with PBC have been admitted $\overrightarrow{\vec{F}}$ to the trial, and randomly allocated to either a treatment group, receiving azathioprine at an initial dose of $2 \mathrm{mg} / \mathrm{kg}$ body weight, or to a control group. $\frac{\bar{\sigma}}{\overline{5}}$

Twenty-two patients have been followed for longer $\frac{\rho}{\widehat{T}}$ than one year, three deaths have occurred, and four $\stackrel{\Phi}{\varrho}$ patients have been withdrawn from the trial because of complications. The clinical course of the two groups has been comparable, but pruritus has decreased in $\overrightarrow{0}$ the treated group. Biochemical tests were not signifi- $\overrightarrow{-}$ cantly different at inclusion in the trial; in the treated $\vec{\omega}$ group there has been a significant fall in alkaline phosphatase, cholesterol, and aspartate transaminase.

Serum immunoglobulin estimations showed a signifi- $=$ cant fall in IgM levels at the start of azathioprine $\overrightarrow{.}$ treatment, but mitochondrial antibody titres did $\vec{N}$ not alter significantly between the groups. Liver histol- $\vec{O}$ ogy after one year has not shown any difference be- $\circlearrowleft$ tween the groups.

Preliminary conclusions are that azathioprine improves aspects of biliary excretion in primary $\vec{\square}$ biliary cirrhosis, but, as yet, there is little evidence of $\mathbb{D}$ an effect on immunology or histology.

DIAGNOSIS AND PROGNOSIS OF PRIMARY MALIGNANT $\stackrel{\overparen{D}}{\longrightarrow}$ TUMOURS OF THE LIVER

P. SHARPSTONE, M. R. Fleisher, M. O. RAKE, K. B. SHILKIN, J. W. LAWS, and ROGER WILLIAMS (Liver Unit, King's College Hospital) Forty-one patients with histologically proven primary malignant tumours of the liver have been seen by the authors. Thirty-four of the patients had hepatocellular carcinoma; three $\frac{\circ}{\mathbb{D}}$ had Kupffer-cell sarcoma; three cholangiocellular carcinoma; and one hepatoblastoma. In 26 patients, $\overline{\bar{O}}$ underlying hepatic cirrhosis was present; nine of 3 them had haemochromatosis. Unusual metabolic effects-hypercalcaemia and porphyria cutanea tarda -were produced by two of the hepatocellular carci- $\vec{c}$ nomas.

Scintiscanning of the liver was the most valuable diagnostic technique. Technetium $99 \mathrm{~m}$ sulphur-colloid scans showed filling defects in all but one of the $28 \%$ patients examined. ${ }^{75}$ Se-selenomethionine scans showed uptake of the isotope in the tumour area in $\mathrm{O}$ 14 of 20 cases. All the Kupffer-cell sarcomas and cholangiocarcinomas failed to take up selenomethio- $\frac{D}{0}$ nine. Selective hepatic arteriography showed diagnostic abnormalities-tumour circulation or avascular $N$ areas-in 15 of 21 examinations.

Thirty-four patients have died; the mean survival $N$ time was 5.8 months. Three of the seven surviving $\omega$ patients have lived for more than two years since diagnosis. A patient with haemochromatosis and a 0 cholangiocellular carcinoma treated with local intra- $\frac{\bar{\Phi}}{\mathscr{D}}$ arterial 5-fluororacil infusion and with irradia- $\stackrel{\mathscr{S}}{\longrightarrow}$ tion, a haemochromatotic with a hepatocellular carcinoma, who had no anti-tumour treatment, and a patient with a hepatocellular carcinoma in a cirrhotic liver, treated with parenteral 5-fluororacil, are $\frac{\rho}{\Phi}$ alive at 56 months, 32 months, and 28 months, respectively.

\section{THE PATHOGENESIS OF COELIAC DISEASE}

MARGOT SHINER and D. H. SHMERLING (Central Middlesex Hospital, London) The response of the jejunal 
epithelial cells and their subepithelial tissues to a single dose of gluten was studied in treated coeliac children and in children without coeliac disease by light and electron microscopy and by immunofluorescent techniques. Serial jejunal biopsies were obtained before gluten challenge and from two to 96 hours after.

The results, based on ultrastructural findings, indicate that following gluten challenge in the coeliac children there is an early thickening of the connective tissue in the subepithelial spaces and around the small blood vessels, with infiltration of mononuclear cells. This was not observed in the children without coeliac disease who, in contrast to the coeliac children, showed epithelial cell changes which may be related to the normal process of polypeptide ingestion and absorption.

In an attempt to demonstrate immune complex formation after gluten challenge within the subepithelial connective tissue of villi and crypts, fluorescein isothiocyanate-conjugated antisera (anti-human gamma globulins:-anti-IgA, anti-IgG, and anti-IgM) were used. The results obtained in the coeliac children, when compared with the non-coeliac children, were suggestive of binding of antigen and antibody in the connective tissue as early as 21 hours following gluten administration. The timing coincided with the earliest reactive changes in the subepithelial layers noted by electron microscopy.

SMALL BOWEL PERMEABILITY IN ANIMALS AND MAN

C. A. LOEHRY and D. PARRISH (Royal Victoria Hospital, Bournemouth) Previous studies on rabbits have demonstrated that the clearance of substances from the blood into the small intestinal lumen is dependent directly on their concentration in the plasma, and inversely on their molecular size (Loehry, Axon, Hilton, Hider, and Creamer, 1970).

The blood-to-lumen transfer in man of creatinine, uric acid, urea, and vitamin $B_{12}$ has been studied with intestinal perfusion through a triple-lumen tube. Both normal subjects and patients in varying degrees of renal failure have been studied, and a direct relationship demonstrated between rising blood levels and intestinal loss.

The differential clearance of fractions of isotopically labelled PVP in the faeces after an intravenous dose has been studied using a Sephadex column. A progressive fall in clearance is demonstrated in fractions of rising molecular weight.

To study the methods by which substances travel from the blood to the lumen various iron preparations have been injected directly into the radicals of the mesenteric artery in rabbits, and the mucosa has been stained for iron. The iron enters epithelial cells near the tips of the villi, but not at their base, or in the crypts. Under certain circumstances iron also passes between epithelial cells near the tips of the villi.

\section{REFERENCE}

Loehry, C. A., Axon, A., Hilton, P., Hider, C., and Creamer, B. (1970). Gut, 11, 6.

THE AMINO ACIDS AND PANETH CELlS OF THE SMALL INTESTINE

A. E. GENT (Introduced by B. CREAMER (St Thomas' Hospital, London) The concept of a homeostatic mechanism for free amino acids in the small intestine was first proposed by Nasset (1957). He showed that considerable amounts of endogenous protein and amino acids enter the intestine in response to food. The purpose of the present experiments was to determine the contribution made by the mucosa to the free amino acids appearing in the intestine. Initial experiments used pilocarpine to stimulate the Paneth cells in the rat small intestine, and showed that a significant increase in amino acid concentrations occurred after its use. Experiments using ${ }^{65} \mathrm{Zn}$ indicated that these amino acids are produced by Paneth cells.

The nature of the homeostatic mechanism was investigated by using amino acid solutions for instillation experiments in rats and perfusion studies in man. The rat experiments indicate that such a homeostatic mechanism does exist, and information from the human studies indicates the importance of pancreatic and Paneth cell secretion. Evidence is presented which suggests that biliary secretion is not an important factor in this mechanism.

The conclusion drawn from these results is that Paneth cell secretion plays an important part in maintaining the homeostatic mechanism for amino acids in the small intestine, second only in importance to the pancreatic contribution.

\section{REFERENCE}

Nasset, E. S. (1957). J. Amer. med. Ass., 164, 172.

THE LOCALIZATION OF ENTEROKINASE TO THE BRUSH BORDER MEMBRANE OF THE GUINEA PIG SMALL INTESTINE

R. W. LOBLEY and R. HOLMES (Department of Gastroenterology, The Royal Infirmary, Manchester) Enterokinase, or enteropeptidase, releases trypsin from trypsinogen and thus initiates the process leading to protein digestion in the small intestine. Nordstrom and Dahlqvist (1970) showed that enterokinase was present mainly in the epithelial cells at or near the villous tips in the rat small intestine, but the subcellular location of enterokinase has not been clearly defined.

To determine the distribution of enterokinase throughout the small intestine of guinea pigs, $5 \mathrm{~cm}$ segments were homogenized and enterokinase levels determined. Enterokinase activity was found only in the first quarter of the small intestine and was undetectable in the distal jejunum and in the ileum.

Brush borders were prepared from the proximal small intestine of guinea pigs, and after Tris-disruption, the resultant microvillous membranes were separated on a glycerol density gradient (Eichholz and Crane, 1965). There was a marked rise in specific activity of enterokinase in the purified brush borders over the mucosal homogenate, and a further increase in specific activity in the brush border membranes. This was similar to the progressive increase in specific activities of sucrase in the same preparations. These results suggest that enterokinase, like sucrase, is a brush border enzyme and that its action on trypsinogen occurs initially at the epithelial cell surface and not in the lumen of the small intestine.

\section{REFERENCES}

Eichholz, A., and Crane, R. K. (1965). J. Cell. Biol., 26, 687. Nordstrom, C., and Dahlqvist, A. (1970). Biochim. biophys. Acta, 198, 621 . 
AN EXPERIMENTAL MODEL OF HUMAN CHRONIC PANCREATITIS

HENRI SARLES (Institut de la Santé et de la Recherche Médicale, Marseille, France) Thirty-eight Wistar rats receiving ad libitum a diet normal in proteins with either $10 \%$ or $34 \%$ of lipids were given a lethal dose of ethanol by gastric intubation for three to 20 days. No pancreatic lesion was observed.

Sixty-one Wistar rats were given ad libitum a standard diet with either $20 \%$ ethanol (45 rats) or water (16 rats) as beverage during 20 to 30 months. Half of the rats drinking ethanol developed pancreatic lesions indistinguishable at the optical microscope level from those observed in the human chronic calcifying pancreatitis (Sarles, Sarles, Camatte, Muratore, Gaini, Guien, Pastor, and le Roy, 1965) with small foci showing atrophy of the acini, augmentation and dilatation of the ducts, calcified protein plugs in the ducts, and sclerosis. In the pancreatic juice of these rats, a spontaneous precipitation of proteins was observed and the protein concentration is significantly higher than in controls.

This experiment provides the first experimental model of chronic pancreatitis identical to the human disease.

\section{REFERENCE}

Sarles, H., Sarles, J. C., Camatte, R., Muratore, R., Gaini, M., Guien, C., Pastor, J., and le Roy, F. (1965). Gut, 6, 545.

THE ROLE OF SERUM TRYPSIN INHIBITORS IN ACUTE PANCREATITIS

O. FITZGERALD and K. F. MCGEENEY (Department of Medicine and Therapeutics, University College, Dublin) The rise in enzymatically determined serum trypsin inhibitors in acute pancreatitis is well documented. However, the behaviour of the individual serum trypsin inhibitors in this condition is not completely understood. The elevation of the serum trypsin inhibitor level in acute pancreatitis is usually seen some time following the acute episode. At the time of the acute episode the level of the serum trypsin inhibitors drops and then comes up again some hours later. The rise is mainly due to $a_{1}$ antitrypsin which can reach a level double the normal value. On the other hand the $a_{2}$ macroglobulin inhibitor does not rebound but remains low.

The pancreatic proteases, notably trypsin, which are bound to $\alpha_{1}$ antitrypsin are enzymatically inactive while those bound to $a_{2}$ macroglobulin form trypsin protein esterase which is active against small molecular weight substrates. In a study in vitro, trypsin protein esterase was found to be an angiotensinase. This would suggest that pancreatic proteases bound to $a_{2}$ macroglobulin may exert an important effect.

AN ENDOCRINE TUMOUR IN KIDNEY AFFECTING SMALL BOWEL STRUCTURE, MOTILITY, AND FUNCTION

M. H. GLEESON, S. R. BLOOM, J. M. POLAK, K. HENRY, and R. H. DOWLING (Departments of Medicine and Pathology, Royal Postgraduate Medical School, Hammersmith Hospital, London W12, and Department of Medicine, Middlesex Hospital, London WI) Ectopic endocrine polypeptide production by tumours is well recognized but their influence on small bowel structure and function has rarely been studied. We report a unique case with altered small bowel structure, motility, and absorptive function associated with an endocrineo renal tumour.

A housewife (aged 44) presented with hypoprotein- $-\overline{\bar{D}}$ aemic oedema, anorexia, and marked constipation, $\vec{\sigma}$ retained faeces producing abdominal distension. $\varrho$ Investigations showed neither proteinuria nor protein- $\tilde{\omega}$ losing enteropathy. Despite constipation she had $\vec{\circ}$ steatorrhoea $\left(20 \mathrm{~g} /\right.$ day), vitamin $B_{12}$ malabsorption, gross indicanuria $(520 \mathrm{mg} / 24$ hours), and a diabetic $\vec{\omega}$ GTT. Repeated barium studies showed grossly dilated $\stackrel{\circ}{\circ}$ small intestine, thickened mucosal folds, and slow transit. Intestinal hypertrophy was confirmed when surgical biopsies showed marked enlargement of villi, easily visible to the naked eye, measuring up to $\vec{N}$ $1,350 \mu(\mathrm{N} 300-800 \mu)$.

Intravenous pyelography showed a renal tumour. After nephrectomy, histology suggested an endocrine $G$ neoplasm with secretory granules on electron micro- $\frac{\rho}{J}$ scopy. Histochemical studies confirmed that the tumour cells contained a polypeptide which showed $\nabla_{\varnothing}$ immunofluorescence with antiglucagon serum. Radio- $\varnothing^{\infty}$ immuno assay of tumour and pre-operative plasma showed high glucagon levels. On bioassay tumour ${ }_{\mathbb{D}}$ extracts showed glucagon-like activity.

Following nephrectomy the small bowel abnor- $\vec{\theta}$ malities promptly disappeared. It is suggested that the $\overparen{O}$ tumour hormone, either glucagon alone and/or another unidentified hormone, was responsible for the small intestinal effects.

INACTIVATION OF GASTRIN AND PENTAGASTRIN IN THE PORTAL CIRCULATION ${ }^{1}$

JOHN M. TEMPERLEY, JOHN H. WYLLIE, and BRIAN H. STAGG (Gastrointestinal and Surgical Units, University College Hospital Medical School, London WC1) The effect on synthetic human gastrin I (SHG) and pentagastrin (PG) of passage through the portal circulation has been studied.

Acid secretion was measured in anaesthetized dogs by washing out the cannulated stomach every ten minutes. SHG was infused (usually at $2 \mu \mathrm{g} / \mathrm{kg} / \mathrm{hr}$ ) alternately into the left external jugular vein and the portal vein in four dogs, or the superior mesenteric artery in another four dogs.

Acid secretion was similar during portal and jugular vein infusions, but during superior mesenteric artery $\sigma$ infusions acid secretion was $60 \%$ of that during jugular N vein infusions. The effect of portal and jugular vein infusions of PG was also studied-acid secretion $\omega$ fell to near basal levels during portal vein infusions. Thus, PG, but not SHG, is inactivated by passage through the liver. SHG has diminished potency after passage through the intestines.

Similarly, in the perfused rat stomach preparation for the bioassay of gastrin (Smith, Lawrence, ColinJones, and Schild, 1970) ligating the superior mesenteric vessels doubled the acid secretory response to standard doses of SHG, but had no effect on the response to standard doses of PG.

In studies in vitro, the rates of inactivation of SHG and PG by homogenates of rat small bowel mucosa and liver were measured by bioassay to be 0.9 and 0.04 nanomoles $/ \mathrm{min} / \mathrm{mg}$ tissue protein respectively ${ }^{1}$ This work was supported in part by the Medical Research Council. 
for SHG and 0 and 20.0 nanomoles $/ \mathrm{min} / \mathrm{mg}$ tissue protein respectively for PG.

\section{REFERENCE}

Smith, G. M., Lawrence, A. J., Colin-Jones, D. G., and Schild, H. O. (1970). Brit. J. Pharmac., 38, 206.

THE EFFECT OF PROTEIN, CARBOHYDRATE, OR FAT ON PLASMA GASTRIN CONCENTRATION IN HUMAN SUBBJECTS

P. C. GANGuli (Medical Research Council, Clinical Endocrinology Unit, Edinburgh) Hansky, Soveny, and Cain (1970) have suggested that protein, carbohydrate, and fat are all potent stimulants of endogenous gastrin secretion but the meals used by these authors were often a mixture of protein, carbohydrate, and fat. In the present study the protein meal consisted of $250 \mathrm{~g}$ grilled lean beef steak ( $55 \%$ protein), the carbohydrate meal was $400 \mathrm{~g}$ rice and sugar (93\% carbohydrate), and the fat meal was $120 \mathrm{~g}$ double cream (93\% fat).

Five healthy human subjects were studied with each meal and thus fifteen subjects took part in this investigation. A sample of blood was taken from the fasting subjects and then they were given the meal; after it blood was sampled at 10, 20, 30, 45, 60, 75, 90, 105,120 , and 150 minutes using an indwelling venous catheter. Plasma gastrin was measured by the radioimmunoassay method of Ganguli and Hunter (1969) reported previously to this Society.

Following the protein meal, there was a rise in plasma gastrin concentration in all five subjects. The peak concentration was reached 30 to 60 minutes after the meal, and was four to five-fold higher than their fasting level; this difference is highly significant $(P<0.001)$. Plasma gastrin concentration then gradually decreased until it reached the fasting level 120 to 150 minutes after the meal. The carbohydrate meal had no significant effect on the fasting plasma gastrin concentration in any of the five subjects, while after the fat meal there was a gradual fall in the plasma gastrin concentration, though this finding was not statistically significant.

The present findings on the effect of these three different meals on the concentration of endogenous gastrin in healthy human subjects are consistent with the earlier observations on the physiology of gastric secretion.

\section{REFERENCES}

Hansky, J., Soveny, C., and Cain, M. D. (1970). Proc. IVth World Congr. Gastroent., 206.

Ganguli, P. C., and Hunter, W. M. (1969). Gut, 10, 413.

REDUCTION IN MUCOSAL BLOOD FLOW AS A FACTOR IN THE DECREASED RESPONSE TO GASTRIN AFTER VAGOTOMY

A. A. HARPER, J. D. REED, D. J. SANDERS, and J. R. SMY (Department of Physiology, Medical School, The University, Newcastle upon Tyne) It has been suggested that the decreased acid response of parietal cells to gastrin after vagotomy may result from a reduction in the affinity of their receptors for gastrin (Grossman, 1970) with a consequent shift of the doseresponse curve to the right (Konturek, Oleksy, and Wysocki, 1968).
In groups of anaesthetized cats with the splanchnic nerves intact and the vagus nerves intact (A) or cut (B) there was no significant difference between the small resting acid secretion, but the mucosal blood flow (MBF), measured by the amidopyrine method, was significantly higher $(\mathrm{P}<0.001)$ in $\mathrm{A}$ than in $\mathrm{B}$. Infusion of pentapeptide $(0 \cdot 1 \mu \mathrm{g} / \mathrm{min})$ produced a significantly higher acid secretion $(\mathrm{P}=0.02)$ and MBF $(\mathrm{P}<0.001)$ in $\mathbf{A}$ than in $\mathbf{B}$.

As the proportion of injected gastrin reaching the parietal cells is related to the MBF, the reduction in blood flow after vagotomy may be a factor in the decreased response to gastrin and shift of the doseresponse curve. This concept is supported by the observation that in vagotomized animals small doses of isopropylnoradrenaline, insufficient by themselves to stimulate acid secretion, increase $\mathrm{MBF}$ and acid secretion during infusion of small amounts of gastrin.

\section{REFERENCES}

Grossman, M. I. (1970). Frontiers in Gastrointestinal Hormone Research, Nobel Symposium XVI.

Konturek, S. J., Oleksy, J., and Wysocki, A. (1968). Amer. J. dig. Dis., 13, 792.

THE EFFECT OF VAGOTOMY ON THE INTESTINAL TRANSPORT OF WATER AND ELECTROLYTES

G. A. BUNCH and R. SHIELDS (Department of Surgery, Welsh National School of Medicine, Cardiff) The cause of diarrhoea as a complication of vagotomy remains unexplained. The possibility that a defect in the intestinal handling of water and electrolytes may explain this diarrhoea has been investigated using a technique of intestinal perfusion.

Using physiological solution containing isotopes and an inert marker, we have studied the intestinal handling of water, sodium, and potassium by perfusing $30-\mathrm{cm}$ segments of jejunum using an orally introduced double lumen tube.

Eleven healthy patients, six patients immediately after a non-intestinal operation, and five patients immediately after vagotomy were studied. Three patients were studied again ten days after vagotomy and three patients who had severe postvagotomy diarrhoea were also studied.

Immediately after operation, the net absorption of water and electrolytes was reduced in all postoperative subjects. The intestinal handling of water and electrolytes was the same in vagotomized and nonvagotomized patients.

Ten days after vagotomy the net absorption of water and electrolytes was no longer reduced and the two-way traffic across the mucosa was similar to that of the healthy control subjects. The patients with established severe postvagotomy diarrhoea demonstrated no abnormality in their intestinal handling of water or electrolytes.

RECURRENT ULCER AND POSTVAGOTOMY GASTRIC ACID SECRETION

C. V. RUCKLEY, W. SIRCUS, C. W. A. FALCONER, W. P. SMAJ_L, and A. N. SMITH (Gastro-Intestinal Unit, Western General Hospital, Edinburgh) The association between incomplete vagotomy and recurrent ulcer is universally recognized. The practical value of this observation is limited by the fact that the majority of patients with positive insulin tests do not develop recurrent ulcer. 
Analyses of the insulin test by criteria other than those of Hollander (Bank, Marks, and Louw, 1967; Gillespie, Gillespie, and Kay, 1968) suggest the possibility of identifying the recurrent ulcer risk more precisely. Pre- and postoperative gastric secretion tests in 226 patients treated by vagotomy and drainage have been examined in respect of basal, maximal, and insulin-stimulated secretion. Twenty-one were diagnosed as having recurrent duodenal or jejunal ulcer. Each insulin test has been interpreted by five criteria (Gillespie $e t$ al, 1968) and scored accordingly. Patients with a $3+$ postinsulin response showed only a $10 \%$ incidence of recurrent ulcer. When the response was $5+$ the incidence was $77 \%$. A 'late-positive' (second hour) response was noted in $19 \%$ of patients with recurrent ulcer. Significant differences in mean basal and 'maximal' acid outputs between recurrent ulcer and non-recurrent ulcer groups were also noted. Postoperative gastric secretion tests can be used not merely to detect the patient at risk of developing recurrent ulcer but also to forecast the degree of risk. This has important implications in the postoperative management of these patients.

\section{REFERENCES}

Bank, S., Marks, I. N., and Louw, J. H. (1967). Gut, 8, 36. Gillespie, G., Gillespie, I. E., and Kay, A. W. (1968). Gut, 9, 470.

\section{HIGHLY SELECTIVE VAGOTOMIES WITHOUT DRAINAGE (HSV) FOR DUODENAL ULCER}

E. AMDRUP, D. JOHNSTON, and J. C. GOLIGHER (Surgical Department I, Kommune Hospitalet, Copenhagen, and University Department of Surgery, The General Infirmary, Leeds) Previous attempts to treat duodenal ulceration by truncal vagotomy alone without drainage procedure gave poor results because of the occurrence of gastric stasis (Dragstedt, Harper, Tovee, and Woodward, 1947). The operation of HSV (Johnston and Wilkinson, 1970), in which the vagal nerve supply to the distal $6 \mathrm{~cm}$ of the stomach is preserved to impart 'vis-a-tergo' to the chyme, has been used previously in man (Holle and Hart, 1967) - but never alone-without drainage or antrectomy.

The insulin test soon after HSV was negative in 50 consecutive patients, but reverted to positive in $40 \%$ of 50 patients re-tested two to 10 months later. Acid outputs, however, were very low. The positive responses may be attributable to vagal release of gastrin. Reductions in spontaneous and maximal (pentagastrin) acid outputs in 100 patients were similar to those achieved by conventional vagotomy.

There have been no deaths or recurrent ulceration. Maximum follow up, however, is only 21 months. Transient food vomiting occurred in two patients, but there was no persisting stasis. Mild dumping or diarrhoea was noted in less than 10 per cent. The results appear to be better than those achieved by vagotomy and drainage, but a prospective trial is needed to prove this.

\section{REFERENCES}

Dragstedt, L. R., Harper, P. V., Jr., Tovee, E. B., and Woodward, E. R. (1947). Ann. Surg., 126, 687.

Johnston, D., and Wilkinson, A. R. (1970). Brit. J. Surg., 57, 289. Holle, F., and Hart, W. (1967). Med. Klin., 62, 441.

THE APPLICATION OF NUMERICAL TAXONOMY TO THE SEPARATION OF COLONIC INFLAMMATORY DISEASE

J. HYWEL JONES, W. CARD, M. CHAPMAN, J. E. LENNARDJONES, B. C. MORSON, M. J. SACKIN, and P. H. A. SNEATH
(St Mark's Hospital, London, University Department of Medicine in Relation to Mathematics and Computing, Glasgow, and Medical Research Council Microbial Systematics Unit, University of Leicester) Some $\overline{\vec{S}}$ workers consider there is such an overlap between $\overrightarrow{0}$ proctocolitis and colonic Crohn's disease that no clear separation can be drawn between them. To $\overline{\bar{\omega}}$ resolve this controversy a prospective analysis was $\vec{\nabla}$

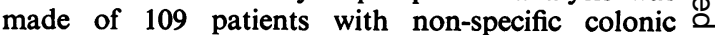
inflammatory disease consecutively admitted to ڤ St Mark's Hospital. Clinical, pathological, and $\vec{\nabla}$ radiological data from these patients were analysed using numerical taxonomic methods.

In the initial computer analysis many of the patients diagnosed as Crohn's disease fell into several small clusters in close proximity to one relatively dense, large cluster which comprised most of the patients diagnosed as proctocolitis. When the analysis was repeated using a limited number of discriminating characters, three relatively large clusters emerged. One contained 67 patients of whom 58 had been diagnosed as proctocolitis; another contained 12 patients, 10 having been diagnosed as Crohn's disease; and the third cluster contained eight patients of whom seven had been diagnosed as Crohn's disease. About half the patients regarded as having Crohn's disease were not included in the clusters.

The results suggest that the disorder now termed proctocolitis comprises a single relatively uniform group of patients which can be distinguished from other types of colitis at present described as Crohn's disease.

\section{REFERENCES}

Lennard-Jones, J. E., Lockhart-Mummery, H. E., and Morson, B. C. (1968). Gastroenterology, 6, 1162.

Sokal, R. R., and Sneath, P. H. A. (1963). Principles of Numerical Taxonomy. Freeman, London.

EVALUATION OF A BAYESIAN MODEL IN THE DIAGNOSIS OF JAUNDICE

R. P. KNILL-JONES, J. D. MAXWELL, R. P. H. THOMPSON, and ROGER WILlIAMS (Liver Unit, King's College Hospital, London) Two hundred patients presenting with jaundice were studied prospectively with final allocation to one of nine separate diagnostic groups on the basis of histological, operative, or necropsy findings. Data were analysed to show which pieces of evidence were most useful in differentiating between the diseases. Selected indicants were used in a Bayesian model to calculate the most likely diagnosis on the initial findings for each patient.

Three indicants obtained from the history (length of illness, age, and duration of itching) were more useful as discriminators than any laboratory or scan measurement. This was reflected in the results from the model; for classification into nine diseases scan measurements gave a correct prediction in $43 \%$ of patients, laboratory tests in $58 \%$, and clinical indicants in $65 \%$. Classification into medical or surgical categories only was correct in $75 \%, 80 \%$, and $82 \%$ of patients respectively, comparing favourably with published reports of clinicians' diagnostic accuracy in a similar situation of about $85 \%$. Combination of all measurements produced some further improvement. 
BILE SALT METABOLISM IN THE NORMAL HUMAN SMALL INTESTINE

T. C. NORTHFIELD, E. CONDILLAC, and I. MCCOLL (Guy's Hospital and St Bartholomew's Hospital, London) The steatorrhoea of the stagnant loop syndrome has been attributed to abnormal bile salt metabolism involving bacterial deconjugation (Tabaqchali, Hatzioannou, and Booth, 1968), but very little attention has been paid to bile salt metabolism in the normal human small intestine.

We have studied small-intestinal samples obtained by intubation from 11 subjects with no known gastrointestinal disease, and at laparotomy in a further five subjects. Free (deconjugated) bile acids have been consistently demonstrated in ileal samples by thin layer and gas/liquid chromatography. Their mean concentration fell from 1.2 to $0.1 \mu$ moles $/ \mathrm{ml}$ following ampicillin $(P<0.02)$, suggesting deconjugation by bacteria, which colonize the normal human ileum (Drasar and Northfield, in press). Total bile acid concentration, however, increased sevenfold following ampicillin $(\mathrm{P}<0.05)$, suggesting impaired absorption. One physiological implication of these findings is that bacterial deconjugation may be an important factor in the remarkable efficiency of the enterohepatic circulation of bile salts, since animal experiments have shown that ileal absorption is considerably more rapid for free than for conjugated bile acids (Dietschy, Salomon, and Siperstein, 1966). One clinical implication is that the presence of free bile acids is only abnormal in jejunal juice, so that it is unnecessary to screen ileal juice in order to exclude the stagnant loop syndrome in a patient with steatorrhoea.

\section{REFERENCES}

Tabaqchali, S., Hatzioannou, J., and Booth, C. C. (1968). Lancet, $2,12$.

Drasar, B. S., and Northfield, T. C. In press.

Dietschy, J. M., Salomon, H. S., and Siperstein, M. D. (1966). J. clin. Invest., 45, 832.

INHIBITORY EFFECT OF NEOMYCIN ON CHOLESTEROL ABSORPTION IN GERM-FREE PIGS

G. R. THOMPSON, K. HENRY, N. EDINGTON, and P. C. TREXLER (Departments of Medicine and Pathology, Royal Postgraduate Medical School, and Department of Pathology, Royal Veterinary College, London) Neomycin is an effective hypocholesterolaemic agent and in large doses also causes steatorrhoea. The hypocholesterolaemic effect has been variously attributed to inhibition of bacterial $7 \alpha$-dehydroxylation of bile acids in the colon (Samuel and Sekowski, 1969), damage to the small intestinal mucosa (Dobbins, Herrero, and Mansbach, 1968), and intraluminal precipitation of cholesterol during absorption (Thompson, MacMahon, and Claes, 1970). This study examines these mechanisms further by determining whether the hypocholesterolaemic action of neomycin is dependent upon its antibiotic properties.

Six germ-free piglets were given an intravenous dose of cholesterol-4-14 $\mathrm{C}$ and their faecal excretion of endogenous neutral sterols and bile acids measured during consecutive two-week periods on and off neomycin sulphate 1-2 g/day. Neomycin significantly increased the mean weekly excretion of neutral sterols from 127 to $269 \mathrm{mg}(\mathrm{P}<0.001)$ but bile acid excretion remained unaltered at 224 and $213 \mathrm{mg} /$ week. Faecal fat excretion was also increased to a slight but significant extent, from 51 to $64 \mathrm{~m}$-equiv/week $(\mathrm{P}<0.02)$. Histology of intestinal mucosa showed no significant changes on light microscopy.

These results support previous evidence that neomycin impairs cholesterol and fatty acid absorption by precipitating mixed micelles within the intestinal lumen. This effect is due to the polybasic nature of neomycin, and not to its antibiotic properties.

\section{REFERENCES}

Samuel, P., and Sekowski, I. (1969). J. clin. Invest., 48, 73.

Dobbins, W. O., Herrero, B. A., and Mansbach, C. M. (1968). Amer. J. med. Sci., 225, 63.

Thompson, G. R., MacMahon, M., and Claes, P. (1970). Europ. J. clin. Invest., $1,40$.

\section{ABSORPTION OF BILE ACIDS BY THE COLON}

JOHN S. MORRIS, K. W. HEATON, and A. E. READ (Department of Medicine, University of Bristol) The study has been designed to investigate the possibility of colonic absorption of bile acids. Patients over the age of 40 years who underwent surgery to the extrahepatic duct system which required postoperative T-tube drainage were studied. During operation sodium taurocholate-24-C $C^{14}$ or cholic carboxyl-C $C^{14}$ acid (Tracerlab (GB) Ltd, Weybridge, Surrey) were injected into the lumen of the ascending or transverse colon. In one patient with permanent $\mathrm{T}$-tube drainage cholic carboxyl-C ${ }^{14}$ acid was introduced into the colon through a sigmoidoscope.

Over the succeeding three or four days all bile draining from the T-tube was collected. After suitable dilution the contained radioactivity was measured in a liquid scintillation counting system. Alcoholic extracts of the bile were separated by thin-layer chromatography, the separated bile acids were identified, and the amount of radioactivity in the primary and secondary bile acids was measured.

Studies in seven subjects show that the colon was able to absorb substantial amounts both of cholic acid and sodium taurocholate. The radioactive label was recovered as conjugated cholate and deoxycholate. These studies expand the observations of Samuel, Saypol, Meilman, Mosbach, and Chafizadeh (1968) who studied the colonic absorption of cholic acid alone.

Together with the observation that patients without a colon have little or no secondary bile acids in their bile or ileostomy effluent (Percy-Robb, Brunton, Jalan, McManus, Gould, and Sircus, 1969; unpublished personal obervations), our data suggest that in man the large intestine is a major site of dehydroxylation of bile acids. They also confirm the ability of the colon to absorb bile acids.

\section{REFERENCES}

Samuel, P., Saypol, G. M., Meilman, E., Mosbach, E. H., and Chafizadeh, M. (1968). J. clin. Invest., 47, 2070.

Percy-Robb, I. W., Brunton, W. A., Telfer, Jalan, K. N., McManus, J. P. A., Gould, J. C., and Sircus, W. (1969). Gut, 10, 1049. (Abstr.)

ABSORPTION OF TRITIATED VITAMIN $\mathrm{K}_{1}$ IN PATIENTS WITH FAT MALABSORPTION

M. J. SHEARER, C. N. MALLINSON, G. R. WEBSTER, and P. BARKHAN (Departments of Haematology, 
Physiology, and Chemical Pathology, Guy's Hospital, and the Gastro-intestinal Unit, Greenwich Hospital, London) Previous work in man using tritiated vitamin $K_{1}\left(K_{1}-{ }^{3} \mathrm{H}\right)$ showed that, following an oral dose, peak blood levels were reached after two to four hours and $8-19 \%$ of the dose was excreted in the urine after three days. About $50 \%$ of the dose was recovered from faeces, $20 \%$ as apparently unchanged $\mathrm{K}_{1}{ }^{-} \mathrm{H}$ and $30 \%$ as more polar metabolites.

Radioactivity levels in blood and urine after oral $\mathrm{K}_{1}{ }^{-}{ }^{3} \mathrm{H}$ given with breakfast have been measured in patients with steatorrhoea from four different causes. (1) In two of four adults with coeliac disease in which radioactivity levels were reduced, effective treatment restored these levels to normal. (2) Three patients with chronic pancreatitis showed markedly reduced levels: in the two most severely affected patients, treatment with Cotazym resulted in normal levels. (3) In a patient with only 18 inches of small intestine remaining after resection, levels were low. (4) In a patient with complete biliary obstruction, no radioactivity was detected in blood or urine: $80 \%$ of the dose was recovered from the faeces, almost all of which was unchanged $\mathrm{K}_{1}{ }^{3} \mathrm{H}$. Only in this last patient was the prothrombin time prolonged. These studies suggest that although vitamin $K_{1}$ absorption is reduced in patients with fat malabsorption, this is probably only clinically important when none is absorbed. The faecal results suggest that the $\mathrm{K}_{1}{ }^{-}{ }^{3} \mathrm{H}$ metabolites originate from biliary excretion.

\section{REFERENCE}

Shearer, M. J., Barkhan, P., and Webster, G. R. (1970). Brit. J. Haematol., 18, 297.

FAMILIAL STEATORRHOEA WITH CALCIFICATION OF THE BASAL GANGLIA AND MENTAL RETARDATION

R. COCKEL, CHARLOTTE M. ANDERSON, EILEEN E. HILL, and C. F. HAWKINS (Queen Elizabeth Hospital and Institute of Child Health, Birmingham, and the East Birmingham Hospital) Two boys and fraternal twin girls, of a sibship of 16 , were seen with steatorrhoea, mental retardation, and calcification of the basal ganglia. The similarity of clinical features and investigative findings suggested a disease of recessive type.

Diarrhoea started in childhood and was associated with irregular passage of voluminous faeces. Episodic abdominal pain occurred with gross distension, sometimes simulating intestinal obstruction. Radiographs showed variable distension and atony of the small bowel, the duodenum being constantly abnormal. Absorption of fat and xylose were abnormal but glucose and disaccharides were absorbed normally. There was no anaemia and serum biochemical values were normal apart from moderate reduction of cholesterol and $\beta$-lipoprotein. Intestinal biopsy and pancreatic secretion were normal. Early growth was normal though attainment of developmental milestones was delayed.

Steatorrhoea was attributed to defective small bowel motility with bacterial colonization causing ineffective action of bile salts. In one patient there was basal gastric hypersecretion, with duodenal $p \mathrm{H}$ between $3 \cdot 5$ and $7 \cdot 4$. The duodenal juice contained Klebsiella aerogenes and deconjugated bile salts.

One boy, aged 15, died after operations for suspected intestinal obstruction; necropsy was performed. The three surviving patients are kept reasonably well on a low fat diet and antibiotics.

\section{STUDIES OF COLONIC CARCINOMA ANTIGENS}

MICHAEL D. TURNER, MARTIN S. KLEINMAN, and LEE HARWELL (Gastroenterology Unit, Department of Medicine, University of Rochester School of Medicineo and Dentistry, Rochester, $N Y, U S A)^{1}$ Antisera were $\frac{-}{\sigma}$ prepared in rabbits by immunization with perchlorate $\overline{\bar{s}}$ extracts of colonic carcinomata. On double immuno- $\vec{\Phi}$ diffusion these sera gave precipitin lines against tumour@ extracts which persisted after absorption of the seraœ with human red cells, plasma,normal colonic mucosa, $\vec{\circ}$ and preparations of colonic bacteria. Two persisting precipitin lines were observed with the original tumour $\vec{\omega}$ extracts and with fractions after gel filtration and electrofocusing. Antiserum donated by $\mathrm{Dr}$ Gold을 also gave two lines of precipitation when tested against some of our extracts: one of these lines gave a reaction $\overrightarrow{-}$ of identity with that given by the antiserum produced $\vec{N}$ here. The results suggest that perchloric acid may extract two antigens from colonic carcinomata. The present $\circ$ studies confirm previous reports of the existence of $\mathrm{G}$

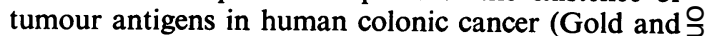
Freedman, 1965a and b; von Kleist and Burtin, 1961) and lend support to the possibility of developing immunological screening tests for this disease.

'Supported by grant no. CA-09546 from the National Cancer Institute, U.S.P.H.S.

\section{REFERENCES}

Gold, P., and Freedman, S. O. (1965a). J. exp. Med., 121, 439. Gold, P., and Freedman, S. O. (1965b). J. exp. Med., 122, 467. Kleist, S. von, and Burtin, P. (1969). Cancer Res., 29, 1961.

INTESTINAL IMMUNOGLOBULIN LEVELS AND BACTERIAL FLORA IN HYPOGAMMAGLOBULINAEMIC ADULTS IN RELATION TO INTESTINAL ABSORPTIVE FUNCTION

D. M. PARKIN, D. B. L. MCCLELLAND, I. W. PERCY-ROBB, R. R. O'MOORE, and D. J. C. SHEARMAN (University Departments of Therapeutics and Clinical Chemistry, The Royal Infirmary, Edinburgh) Five patients with 3 adult-onset panhypogammaglobulinaemia and one with isolated IgA deficiency were studied together with control subjects. Gastric and jejunal juice was obtained for immunoglobulin estimations and immedi- 윽 ate aerobic and anaerobic culture. Jejunal aspirates $D$ were also tested for deconjugated bile acids by thinlayer chromatography and individual organisms were tested for deconjugating ability in vitro.

All patients with panhypogammaglobulinaemia N had large numbers of Giardia lamblia in the jejunal $N$ aspirate: this organism was not found in the IgA- $\omega$ deficient patient or the controls. Bacterial counts, especially of 'enteric' organisms (coliforms and 읃 bacteroides), tended to be greater in the patients with $\mathbb{尺}$ panhypogammaglobulinaemia than in controls and the IgA and IgM levels were much lower, the one $\square$ exception being the IgA-deficient patient whose jejunal IgM level was high normal. Fat malabsorption was found in three of the panhypogammaglobulinaemic patients, and deconjugated bile salts were detected in the aspirates from all these patients. It is concluded that the abnormal bacterial flora in $\delta$ panhypogammaglobulinaemia relates to deficiency in intestinal immunoglobulin, although IgM appears able to compensate in the case of isolated IgA deficiency. The resultant abnormal flora may interfere 
with bile salt metabolism and affect intestinal absorption. The possible role of the Giardia in the presence of malabsorption is not yet clear.

IMPAIRED INTESTINAL SUGAR TRANSPORT IN BLIND-LOOP RATS in vivo

MICHAEL GRACEY, VALERIE BLRKE, ADEMOLA OSHIN, and CHARLOTTE M. ANDERSON (Institute of Child Health, University of Birmingham, Birmingham) The occurrence of impaired D-glucose tolerance in patients with the blind-loop syndrome (Donaldson, 1967) and temporary monosaccharide malabsorption in some babies with bacterial contamination of the small bowel (Gracey, Burke, and Anderson, 1969) suggests that impaired carbohydrate absorption may be related to bacterial overgrowth in the small intestine.

The absorption of Arbutin ( $\mathrm{p}$-hydroxyphenol- $\beta$ glucoside), an analogue of glucose which shares the same active transport pathway (Alvarado and Crane, 1964) but is not metabolized, was studied in female adult Wistar rats with midjejunal blind loops, one to three months after operation. In the anaesthetized rat, segments of jejunum proximal and distal to the blind loop and measuring approximately $20 \mathrm{~cm}$ in length were used for perfusion. This was done for one hour at $10 \mathrm{ml} /$ hour with Krebs-Henseleit bicarbonate buffer containing $10 \mathrm{mM}$ Arbutin and polyethylene glycol as a non-absorbable marker, at $37^{\circ} \mathrm{C}$ and $p \mathrm{H} 7.4$ and perfusate collected continuously. The amount of Arbutin transported across the segment was calculated by difference and expressed as $\mu$ moles/ $\mathrm{cm}$ of intestine/hour.

Control rats (17) transported $2 \cdot 02 \pm 0.27 \mu$ moles/ $\mathrm{cm} /$ hour. In the blind loop rats the proximal segments (5) transported $1.51 \pm 0.58(\mathrm{P}<0.1)$ while the distal segments (5) transported $1 \cdot 21 \pm 0 \cdot 36$, which is significantly less than the control value $(P<0.001)$.

\section{REFERENCES}

Donaldson, R. M., Jr. (1967). Fed. Pro., 26, 1426.

Gracey, M., Burke, V., and Anderson, C. M. (1969). Lancet, 2, 384.

Alvarado, F., and Crane, R. K. (1964). Biochim. biophys. Acta, 93, 116.

MANNITOL UTILIZATION IN THE STAGNANT LOOP SYNDROME

P. R. SAlmon, A. B. AJDUKIEWICZ, J. R. ClAMP, and A. E. READ (Department of Medicine, University of Bristol) At the present time there is no simple screening or absorption test which will predictably demonstrate small-bowel bacterial contamination (Hamilton, Dyer, Dawson, O’Grady, Vince, Fenton, and Mollin, 1970).

This study was designed to investigate bacterial metabolism of the poorly absorbed (Fordtran, Rector, Ewton, Soter, and Kinney, 1965) and nonmetabolized sugar alcohol mannitol in patients with the stagnant loop syndrome.

Six normal subjects and 17 patients with radiological evidence of a blind loop syndrome were each given $2.5 \mathrm{~g}$ of D-mannitol labelled with a tracer of D-mannitol-1-14C. Radio-carbon breath excretion was measured over five hours using the method described by Salmon, Read, and McCarthy (1969). A further six normal subjects were given $2.5 \mathrm{~g}$ of D-mannitol and urinary mannitol excretion was measured over five hours by gas chromatography. The results were compared with urinary indican excretion, bacteriology of the small bowel contents, and in-vitro bacterial metabolism of tryptophan and mannitol.

It was shown that normal subjects absorbed less than $10 \%$ and metabolized less than $2 \%$ of the ingested mannitol in five hours. On the other hand those with the stagnant loop syndrome metabolized on average $13.2 \%$ of the mannitol within five hours. These results correlated with in-vitro bacterial metabolism of mannitol. Urinary indican levels were normal in six patients with bacterial contamination of the small bowel.

It is suggested that a test based on radio-carbon breath excretion may be used to determine the presence and metabolic activity of small bowel bacteria.

\section{REFERENCES}

Hamilton, J. D., Dyer, N. H., Dawson, A. M., O'Grady, F. W. Vince, A., Fenton, J. C. B., and Mollin, D. L. (1970). Quart. J. Med.. 154, 265

Fordtran, J. S., Rector, F. C., Jr., Ewton, M. F., Soter, N., and Kinney, J. (1965). J. clin. Invest., 44, 1935.

Salmon, P. R., Read, A. E., and McCarthy, C. F. (1969). Gut, 10,685 .

OSTEOMALACIA IN ADULT COELIAC DISEASE

PH. BORDIER, D. HIOCO, G. HEPNER, D. E. EDWARDS, F. H. DOYLE, and C. C. BOOTH (Unité de Recherche sur le Métabolisme Phospho-calcique, Hôpital Lariboisière, Paris, France, and the Royal Postgraduate Medical School, London) Osteomalacia is a recognized complication of adult coeliac disease. Reported differences in its incidence may reflect differences in diagnostic criteria (Melvin, Hepner, Bordier, Neale, and Joplin, 1970). We present an investigation of 17 unselected adults with untreated coeliac disease. Iliac bone biopsy was studied by quantitative histological techniques (Matrajt, Bordier, and Hioco, 1967). Total bone and osteoid were expressed as percentages of total bone volume. Osteoid was also measured as a percentage of cancellous bone surface covered with osteoid. The proportion of osteoid surface associated with a calcification front was determined (Bordier, Matrajt, Hioco, Hepner, Thompson, and Booth, 1968).

Using empirical histological criteria, patients were assigned to three groups: normal (seven patients), mild osteomalacia (five patients), and severe osteomalacia (five patients). Using statistical techniques of discriminant analysis, analysis of variance and multiple regression, it was shown that: (1) When all variables were used, each patient was assigned to the 'correct' group with an estimated $P$ value $>0.999$. (2) None of the biochemical measurements, either singly or in groups, could discriminate effectively. (3) Severe osteomalacia was associated with higher levels of total bone, osteoid and serum alkaline phosphatase. The proportion of osteoid surface with a calcification front, serum calcium and inorganic phosphate decreased with increasing severity of bone disease. (4) Osteoid and surface osteoid were moderately correlated $(\mathrm{P}<0.01)$ with serum alkaline phosphatase. Total bone and the proportion of osteoid with a calcification front were less well correlated with alkaline phosphatase $(\mathrm{P}<0.05)$.

\section{REFERENCES}

Melvin, K. E. W., Hepner, G. W., Bordier, Ph., Neale, G., and Joplin, G. F. (1970), Quart. J. Med., 39, 83. 
Matrajt, H., Bordier, Ph., Hioco, D. (1967). In L'Osteomalacie, edited by D. Hioco, p. 101. Masson et Cie, Paris.

Bordier, Ph., Matrajt, H., Hioco, D., Hepner, G. W., Thompson, G. R., and Booth, C. C. (1968). Lancet, 2, 437.

THE MUCOSAL CONTRIBUTION TO NON-DIETARY LIPID IN THE INTESTINAL LUMEN

PETER B. COTTON, introduced by B. Creamer (St Thomas' Hospital, London) Endogenous (non-dietary) intestinal lipid may be derived from the mucosa (by cell loss and exudation) and from bile and bacteria. The mucosal contribution has been assessed by perfusing the entire small intestine of fasting anaesthetized rats, with bile excluded. The cell and lipid contents of these perfusates, and of suspensions of isolated intestinal cells, were measured by DNA analysis, and by a specially developed method of quantitative thinlayer chromatography. The rate of cell loss obtained was within the physiological range.

It was shown that lecithin, phosphatidyl ethanolamine, cholesterol, cholesterol ester, and triglyceride enter the intestinal lumen only in cellular form, whereas some non-esterified fatty acid is freely exuded independently of cells.

In fasting rats, lipid exfoliation and exudation averaged $3 \mathrm{mg} /$ hour $(250 \mathrm{mg} / \mathrm{kg} / \mathrm{day})$, the majority of which must normally be reabsorbed.

From published estimates of the lipid content of human intestinal cells and of daily intestinal cell loss (Croft, 1970), it appears that 10-25 $\mathrm{g}$ of lipid is normally exfoliated each day into the small intestine of fasting man. When cell loss is increased and absorption impaired, steatorrhea may result partly from exfoliation and exudation of endogenous lipida state of fat-losing enteropathy.

\section{REFERENCE}

Croft, D. N. (1970). Proc. roy. Soc. Med., in press.

MUCOSAL ABNORMALITIES AND DISACCHARIDASES IN PERNICIOUS ANAEMIA

A. S. PEÑA, S. C. TRUelove, SHEIlA T. CALlENDER, and R. WHITEHEAD (The Radcliffe Infirmary, Oxford) Patients with untreated pernicious anaemia may show morphological abnormalities of the small-intestinal mucosa (Sauli, Astaldi, and Malossine, 1963; Foroozan and Trier, 1967). Abnormalities of the smallintestinal mucosa are frequently associated with depressed disaccharidase levels. We have therefore studied the disaccharidase levels in patients with pernicious anaemia, both before and after treatment with vitamin $\mathbf{B}_{\mathbf{1 2}}$.

Six patients with untreated pernicious anaemia were biopsied from the duodenojejunal flexure with a Crosby capsule immediately before treatment with vitamin $\mathbf{B}_{12}$ was started. Four of these patients showed partial villous atrophy on light microscopy; the other two had a normal villous pattern. The first four patients were re-biopsied at four to seven days after $1,000 \mu \mathrm{g}$ vitamin $B_{12}$ had been given intramuscularly, and all of them showed a marked improvement in the villous pattern.

Another six patients with pernicious anaemia who had been treated for varying periods of time were also biopsied and showed an entirely normal small-intestinal mucosa.

The levels of the disaccharidases were low in the patients with untreated pernicious anaemia. When compared with the treated group and with a group of 19 normal volunteers there were significant differences. The four patients who were re-biopsied after treatment with vitamin $B_{12}$ showed a rise in the values of all the disaccharidases.

These abnormalities in the small-intestinal mucosa $\overline{\bar{c}}$ in untreated pernicious anaemia were not associated $\stackrel{\oplus}{\widetilde{\Phi}}$ with significant clinical symptoms.

Both the morphological abnormalities and the depressed enzyme levels probably reflect the adverse effect of vitamin $B_{12}$ deficiency on DNA synthesis.

\section{REFERENCES}

Sauli, S., Astaldi, G., and Malossine, L. (1963). Acta vitamin.ت (Milano), 17, 43.

Foroozan, P., and Trier, J. S. (1967). New Engl. J. Med., 277, 553. Hepner, G., and Herbert, V. (1969) Fed. Proc., 28, 513.

THE FATE OF ILEORECTAL ANASTOMOSIS IN CROHN'S G DISEASE OF THE LARGE BOWEL

J. H. BURMAN, J. ALEXANDER WILlIAMS, and W. T. COOKE (The General Hospital, Birmingham) An assessment has been made of the results of ileorectal $\frac{\mathbb{D}}{3}$ anastomosis in 25 patients with Crohn's colitis using anastomotic leak and disease recurrence as indices of short- and long-term morbidity.

Leaks occurred in eight patients $(32 \%)$ despite temporary ileostomy in two and irrespective of whether the anastomosis was made through diseased rectum or not. The occurrence of a leak had no long-term prognostic significance. The incidence of leakage and $\bar{\partial}$ of recurrence was unaffected by the administration of steroids, age at operation, or duration of illness. $\frac{\mathbb{Q}}{\mathrm{Q}}$ Sigmoidoscopic findings before operation gave no indication as to the likelihood of leak or future recurrence although the relatively normal appearances must have influenced the decision to perform an $\frac{2}{0}$ ileorectal anastomosis.

One patient (who also had severe amyloid disease) died as a result of operation. Two patients died subsequently: one with severe recurrence and one with $\frac{0}{3}$ hypertension. Two patients, who have had revision ileorectal anastomoses and five who now have ileos- o tomies, are well. Nine patients have not developed 3 recurrence and are well $(36 \%)$. The overall disease 음 recurrence rate was $60 \%$ and the mortality rate $12 \%$. The incidence of pre-stomal ileitis in 31 patients treated by panprocto-colectomy alone is $52 \%$.

\section{REFERENCES}

Jones, J. H., Lennard-Jones, J. E., and Lockhart-Mummery, H. (1966). Gut, 7, 448.

Hawke, W., and Turnbull, R. (1966). Gastroenterology, 51, 802. Lindner, A., Marshak, R., Wolf, B., and Janowitz, H. (1963). 具 New Engl.J. Med., 269, 379.

COELIAC DISEASE, VASCULITIS, AND CRYOGLOBULINAEMIA

W. F. DOE, D. J. EVANS, J. R. HOBBS, and C. C. BOOTH (Departments of Medicine, Pathology, and Chemical Pathology, Royal Postgraduate Medical School, 응 London) Adult coeliac disease has previously been $\leqq$ associated with a variety of skin disorders. This paper $\frac{\bar{Q}}{\overrightarrow{2}}$ describes four patients with adult coeliac disease who ? 
developed vasculitis associated with cryoglobulinaemia, a hitherto unrecognized association.

All four patients had a rash, similar to that found in patients with cryoglobulinaemia, but in only two were there episodes of Raynaud's phenomenon. The histological appearances of the skin showed a nonspecific vasculitis with polymorphonuclear infiltration and in one case there was a necrotizing arteritis involving skin and muscle alone. Serum from these patients separated at $37^{\circ} \mathrm{C}$ showed a cryoprecipitate on standing at $4^{\circ} \mathrm{C}$. The cryoglobulin was shown to contain polyclonal IgG and IgM in one case, and in two other patients the cryoprecipitate formed at $4^{\circ} \mathrm{C}$ contained a mixture of $\operatorname{IgM}, \operatorname{IgG}$, and IgA. Rheumatoid factor and direct antiglobulin tests were positive in all three patients studied. These findings were typical of a secondary or mixed type cryoglobulinaemia. In two patients the rash responded satisfactorily to steroid therapy, but in the other two cases, both suffering from severe coeliac disease, unresponsive to continued treatment, steroid therapy had no effect on the rash and both these patients died. These findings may be related to circulating immune complexes in patients with severe coeliac disease, or alternatively may reflect a biochemical abnormality suggestive of early malignant change.

\section{The November 1970 Issue}

\section{THE NOVEMBER 1970 ISSUE CONTAINS THE FOLLOWING PAPERS}

Quantitative measurement of iron stores with diethylenetriamine penta-acetic acid MICHAEL BARRY, GUISEPPE CARTEI, AND SHEILA SHERLOCK

Measurement of iron stores in cirrhosis using diethylenetriamine penta-acetic acid MICHAEL BARRY, GUISEPPE CARTEI, AND SHEILA SHERLOCK

Ultrastructure of the liver in non-cirrhotic portal fibrosis with portal hypertension B. N. TANDON, R. LAKSHMINARAYANAN, S. BHARGAVA, N. C. NAYAK, AND S. K. SAMA

Pancreatic islet cell tumour with watery diarrhoea and hypokalaemia D. J. STOKER AND v. WYNN

Corticosteroid or corticotrophin therapy in Crohn's disease (regional enteritis) w. T. COOKE AND J. F. FIELDING

A comparative radiographic and pathological study of intestinal vaso-architecture in Crohn's disease and in ulcerative colitis F. BRAHME AND C. LINDSTRÖM

Surgery in amoebic colitis D. STEIN AND SIMMY BANK
Further studies on the perfusion method for measuring intestinal absorption in man: The effects of a proximal occlusive balloon and a mixing segment G. E. SLADEN AND A. M. DAWSON

Gastric acid secretion in Chinese with particular reference to the dose of histamine required for maximal stimulation WYE POH FUNG

Plasma insulin response to oral carbohydrate in patients with glucose and lactose malabsorption J. D. MAXWELL, MARGARET T. MCKIDDIE, ANNE FERGUSON, AND K. D. BUCHANAN

\section{Technique}

A genteel device for collecting faeces E. S. PRYKE AND H. M. WHYTE

\section{Progress report}

New developments in the therapy of amoebiasis S. J. POWELL

\section{Progress report}

Gastrointestinal polyposis H. J. R. BUSSEY

Notes and activities

Copies are still available and may be oblained from the PUBLISHING MANAGER, BRITISH MEDICAL ASSOCIATION, TAVISTOCK SQUARE, WC1H 9JR price 17s. 6D. 